University of Minnesota Morris Digital Well

University of Minnesota Morris Digital Well

English Publications

Faculty and Staff Scholarship

Summer 2006

\title{
Modernist Anti-Philosophicalism and Virginia Woolf's Critique of Philosophy
}

\author{
Michael Lackey \\ University of Minnesota Morris, lacke010@morris.umn.edu
}

Follow this and additional works at: https://digitalcommons.morris.umn.edu/eng_facpubs

Part of the Literature in English, British Isles Commons

\section{Recommended Citation}

Lackey, Michael, "Modernist Anti-Philosophicalism and Virginia Woolf's Critique of Philosophy" (2006).

English Publications. 21.

https://digitalcommons.morris.umn.edu/eng_facpubs/21

This Article is brought to you for free and open access by the Faculty and Staff Scholarship at University of Minnesota Morris Digital Well. It has been accepted for inclusion in English Publications by an authorized administrator of University of Minnesota Morris Digital Well. For more information, please contact skulann@morris.umn.edu. 


\section{凹 INDIANA UNIVERSITY PRESS}

\section{Modernist Anti-Philosophicalism and Virginia Woolf's Critique of Philosophy}

Author(s): Michael Lackey

Source: Journal of Modern Literature, Vol. 29, No. 4 (Summer, 2006), pp. 76-98

Published by: Indiana University Press

Stable URL: https://www.jstor.org/stable/3831881

Accessed: 06-03-2020 21:07 UTC

JSTOR is a not-for-profit service that helps scholars, researchers, and students discover, use, and build upon a wide range of content in a trusted digital archive. We use information technology and tools to increase productivity and facilitate new forms of scholarship. For more information about JSTOR, please contact support@jstor.org.

Your use of the JSTOR archive indicates your acceptance of the Terms \& Conditions of Use, available at https://about.jstor.org/terms 


\title{
Modernist Anti-Philosophicalism and Virginia Woolf's Critique of Philosophy'
}

\author{
Michael Lackey \\ Wellesley College
}

$\mathbf{O}$ $\mathrm{n}$ the topic of Virginia Woolf and philosophy, there have been many outstanding studies. Lucio Ruotolo uses Martin Heidegger's existential analysis of Dasein to illuminate Clarissa Dalloway's complex interaction with nothingness, "the void that borders meaning" (17); Mark Hussey uses the phenomenological theory of Maurice Merleau-Ponty to define the "ambiguous self" in its relation to a numinous "reality" in Woolf's novels; Pamela Caughie develops "a conceptual model," which is based on Ludwig Wittgenstein's philosophy of language, "for narrative discourse [...] in terms of the multiple and shifting relations among signifying systems" (81) in order to analyze and interpret Woolf's corpus; and Ann Banfield uses Bertrand Russell's "symbolic logic" to shed light "on Woolf's thinking about language" (42-43). That the authors of these studies have intelligently and convincingly illuminated Woolf's work through these philosophers' systems is certain, but one can only wonder if Woolf, given her view of philosophy, would have been so eager to have her works analyzed from a philosophical perspective. After all, philosophy was a discipline in crisis during Woolf's day, and a casual glance at philosophy and the philosopher in Woolf's works indicates not just that she was aware of the unparalleled assault on philosophy's most treasured axioms and methods, but that she was also trying to deliver the deathblow to philosophy itself. Given Woolf's blatant critique of philosophy, I argue that using philosophy to analyze and interpret her corpus places the critic at odds with Woolf's political and aesthetic agenda. There are three stages to my argument. In the first, I provide a brief history of the early-twentieth century crisis in philosophy. In the second, I examine Woolf's treatment of philosophy and the philosopher in light of this crisis. In the third, I draw a conclusion about Woolf's response to and ultimate rejection of philosophy. 
I.

"The appartement of the Boulevard des Philosophes presented the dreary signs of impending abandonment. It looked desolate and as if already empty to my eyes."

-(Joseph Conrad, UNDER WESTERN EYES 275)

In the Western intellectual tradition, philosophy has been defined as a discipline that makes use of rigorous forms of logic in order to apprehend an overarching ahistorical truth, which is embodied in either an Ideal Form or a universal concept. Given the superior nature of philosophy's intellectual tools and primary object of desire, it has been dubbed a "nonempirical super science" (Rorty, Contingency 4), a disciplinary touchstone used to determine the quality and value of all other systems of knowledge. ${ }^{2}$ On this view, a discipline has legitimacy and worth insofar as it contributes to, approximates, or yields philosophical knowledge. Philosophy certainly dominated the Western intellectual tradition from Plato to the end of the nineteenth century, but by 1899, Bertrand Russell was suggesting that philosophy was on the verge of losing its title as the Monarch of knowledge and truth: "Philosophy, by the slow victories of its own offspring, has been forced to forgo, one by one, its high pretensions" (95).

What, in part, accounted for philosophy's demotion on the sociointellectual chain of being was the legitimation of psychology as an independent discipline. Toward the end of the nineteenth century, "psychology," which "was much more closely affiliated with philosophy than it is today," "began to emancipate itself as a discipline" (Ryan 2). Such a split had enormous ramifications, for while philosophy conceived of the human primarily in terms of the mind, an ahistorical and universal thinking faculty that uses logic to ascertain immutable, non-relative Truth, psychology conceived of the human primarily in terms of the psyche, a culturally-specific thinking faculty that knows only in relation to its cultural context. Martin Jay intelligently articulates the threat that the emancipation of psychology posed to philosophy: "Reducing the mind to the psyche was problematic for logic and mathematics because it opened the door to relativism in which truth was merely a function of the specific thinking mind in which it appeared or of its cumulative experience over time" (95). In short, psychology's emancipation forced modernists to choose between philosophy's metaphysical mind, which has the capacity to apprehend non-normative and non-relative Truth, or psychology's culturally embedded psyche, which has the capacity to know only in relation to its culture's provisional truths. Russell noted this shift from philosophy to psychology when he was still a member of that intensely philosophical organization known as the Cambridge Apostles. As S. P. Rosenbaum notes, Russell witnessed in the early twentieth century how 
"philosophy and politics [were] being replaced" among the Apostles "by introspective analyses of shades of feeling" (174). So for someone heavily influenced by the Apostles, like Virginia Woolf, who had to choose between philosophy's metaphysical mind and its absolute Truth or psychology's culturally-embedded psyche and its historically-constructed "truth," she claims that modernists chose psychology: "For the moderns 'that', the point of interest, lies very likely in the dark places of psychology" ("Modern" 152). ${ }^{3}$

Deeply concerned about the radical subversion of philosophy was T.E. Hulme, the modernist aesthetician who understood the threat that the anthropomorphic turn in knowledge posed to Truth. For Hulme, should the intellectual world accept the view that truth is a human construction instead of a pre-given Idea, all conceptual systems would be nothing more than a Weltanschauung. To save universal Truth and objective Reality, therefore, modernist intellectuals have only one option: to purge philosophy of "anthropomorphism" so that they could re-establish an "objective basis" for knowledge, a basis that does "not in the least depend on the human mind." Once philosophy has purged itself of the anthropomorphic or empirical prejudice, "it becomes possible to think of certain 'higher' concepts, those of the good, of love, etc., as, at the same time, simple, and not necessarily to be analysed into more elementary (generally sensual) elements" (45). For Hulme, when Truth is tainted by the sensual or the anthropomorphic, it is corrupt and thereby loses its metaphysical character. In other words, "truth" that is anthropomorphic or sensual is not Truth.

At the same time that Hulme (late teens and early 1920's) was trying to rehabilitate and reground philosophy so that the intellectual community could recover epistemological certainty and epistemic authority, Ludwig Wittgenstein was furthering the project of undermining philosophy in his groundbreaking book Tractatus Logico-Philosophicus (1921). Since the "sense of the world must lie outside the world" (183 [6.41]) philosophy has no choice but to recognize its limits, which is to say that philosophy, according to Wittgenstein, could no longer lay epistemological claim to aesthetic, ethical, or metaphysical knowledge. Given this situation, Wittgenstein endorsed a philosophical silence, a silence that he would maintain for nearly ten years (1919-1928). ${ }^{4}$ But even after Wittgenstein re-entered the intellectual scene, he did not change his position about philosophy: "The nimbus of philosophy has been lost" (Wittgenstein's Lectures 21). While Wittgenstein may have broken his post-Tractatus silence, he never gave philosophy back the ladder it had once used to ascend into the metaphysical heaven of Ideas.

This inability to apprehend a metaphysical Truth certainly posed a major challenge to philosophy, but it was the suggestion that philosophers are- of necessity - epistemologically defective that ultimately led so many modernists to reject the discipline. Primarily governed by reason, philosophy only acknowledges the existence of that which is conscious or rational, and as a consequence, 
it renders that which is non-conscious or non-rational ontologically negligible. To put this in the words of Sigmund Freud, "To most people who have been educated in philosophy the idea of anything psychical which is not also conscious is so inconceivable that it seems to them absurd and refutable simply by logic" (Ego 3). Philosophy treats that which is conscious and rational as having legitimate existence, while that which is non-rational does not exist in the strict sense of the word. ${ }^{5}$ In terms of Freudian psychology, the non-rational contents of the unconscious have no true existence for philosophers and are therefore not worth considering. ${ }^{6}$

D.H. Lawrence makes a similar case against philosophy in his posthumously published essay "Why the Novel Matters." For Lawrence, those "damned philosophers" have misled everyone by asserting their intellectual superiority. Indeed, the philosopher, "because he can think, decides that nothing but thoughts matter" (535). Philosophers give thoughts ontological priority because they are immutable and universal. According to this logic, that which is mutable and contingent is not just ontologically inferior, it does not exist in a strict sense. Aldous Huxley develops this idea in some detail through the character of Mark Rampion, who is based on Lawrence, in his novel Point Counter Point. Rampion makes a distinction between "human truth," which is a human-constructed concept that assumes a provisional form in and through a semiotic sign, and "non-human truth," which is the philosopher's mindindependent Concept, subject neither to decay nor change (398). For Rampion, "the non-human truth isn't merely irrelevant; it's dangerous" (399). This is the case because those in pursuit of the "non-human truth" invariably distinguish the relative matters of the ephemeral world (what Rampion refers to as "secondary qualities") from the absolute matters (primary qualities) of the objective world. Put in more concrete terms, the spiritual soul is superior to the human body, just as the immaterial mind is superior to the contingent psyche. For Rampion, this distinction can only have disastrous consequences for individual beings: "it's an established non-human truth - or at least it was established in my young days - that secondary qualities have no real existence" (399). By adopting this view, many philosophers have sought eternal Truth and have totally blinded themselves to the contingent, psyche-bound "self." After all, the psychic "self," as a secondary quality, has no real existence. But since "secondary qualities" are "the only real ones," philosophers in pursuit of a phantom absolute do irreparable damage to themselves because their search for a non-human truth is not only futile (since no such truth exists) but dangerous (since the absolute makes secondary qualities seem negligible and irrelevant).

Perhaps the most comical and vicious representation of philosophy can be found in Huxley's "First Philosopher's Song," a poem from the 1920 volume Leda. Aware of his physical inferiority to the ape, the narrator notes that humans can only assert their superiority with their "mind." Given this logic, 
the more humans valorize the mind, the more they can justify their dominance over the animal kingdom. Therefore, using the "Mind fabulous, mind sublime and free," the philosopher, who is "Greedy of luscious truth," wends his way "through the mangrove maze / Of metaphysics," and thereby intellectually "Outruns the hare, outhops the goat." But since mind, instead of being a noncontingent, immaterial faculty of a spiritual soul, is actually just "a nimbler beast," Huxley implicitly exposes the philosopher's metaphysical faculty as a Darwinian creation, a human-constructed tool to ensure the survival of the fittest. In other words, metaphysical truth and the immaterial mind are, not ontological facts of being, but instrumental fictions that humans have constructed to secure power and dominion over brute beasts. To conclude the poem, therefore, Huxley's narrator puts the philosopher in his rightful place:

But oh, the sound of simian mirth!

Mind, issued from the monkey's womb,

Is still umbilical to earth,

Earth its home and earth its tomb.

The joke is ultimately on the philosopher, for whatever pretence he has once had to superiority over the animal kingdom, whatever belief he has held of the ascending ladder of Knowledge into a metaphysical Heaven of Ideas, the secular truth has now been revealed through the smirk of a mindful monkey.

This all-too-brief description of modernist anti-philosophicalism should provide an adequate backdrop for understanding Woolf's uncharitable depiction of philosophy and philosophers.

II.

"just as every porter wants to have an admirer, so even the proudest of men, the philosopher, supposes that he sees on all sides the eyes of the universe telescopically focused upon his action and thought."

- Friedrich Nietzsche,

"ON Truth and Lies in a

Nonmoral Sense" 79)

In the 1928 novel Orlando: A Biography, Woolf's narrator refers to "philosophy" or "the philosophers" seven times. ${ }^{7}$ These references are neither random nor haphazard. Indeed, they strategically chart the decline and ultimate demise of philosophy. The first two references occur during the reign of King James I in the seventeenth century, when philosophy still stood guard before the door of the Truth. Given philosophy's superior standing within the culture, the philosophers' words carry considerable epistemic authority, which Woolf's narrator underscores by turning to the philosophers to legitimate a particular 
viewpoint. For instance, when Orlando's mood swings from euphoria to despair, the narrator interjects: "the philosopher is right who says that nothing thicker than a knife's blade separates happiness from melancholy" (45). In a scene only sixteen pages later, philosophers are invoked again. When the Thames, which "had been solid ice of such thickness that it seemed permanent as stone" (61-62), undergoes an almost instantaneous thaw, it was dubbed "a sulphur spring," a reference that gains legitimacy because it is one "to which many philosophers inclined" (62). The philosophers are called upon again later in the novel to explain Orlando's transformation from man to woman. After the metamorphosis, Orlando becomes "more modest" and "more vain" (187). The reason, "some philosophers will say" (187), is the "change of clothes." It is at this point, however, that the philosophers' perspective is dismissed, for as the narrator interjects: "This is the view of some philosophers and wise ones, but on the whole, we incline to another" (188). From this point on, philosophy is mentioned only twice, but the philosophers are never invoked again to legitimize a particular idea or way of thinking. In fact, within the historical context of Orlando, philosophy dies in the nineteenth century, for once the novel enters the twentieth century, there are no more references to philosophy or the philosophers.

This is the case because of the shift in the intellectual community's view of knowledge. Richard Rorty can help shed some light on this shift. In his recent essay, "Analytic and Conversational Philosophy," Rorty defines traditional and analytic philosophy's orientation toward knowledge in terms of "an overarching ahistorical framework of human existence that philosophers should try to describe with greater and greater accuracy" (27). Implicit in this view is the belief that there exists a mind-independent Concept that is what it is whether humans perceive it or not. Moreover, this Concept is best suited to represent the world's essence or nature. Therefore, the task of the philosopher is "to pin down" this invariable and universally valid Concept (21) so that he or she can represent Reality. Starting with Hegel, however, concepts were treated "like persons - never quite the same twice, always developing, always maturing" (21). This is, according to Rorty, the conversational philosopher's view of the "concept." Instead of being an immutable, mind-independent reality, it is a human-constructed semiotic force that evolves in relation to specific communities of language users. The idea of getting a concept right, therefore, is simply incoherent.

While Rorty uses this distinction between the immutable and evolving concept as a way of distinguishing analytic from conversational (his term for non-analytic) philosophy, Woolf makes the same distinction in order to distinguish the age of philosophy from the post-philosophical age. Let us see how this works in Orlando. Immediately after the narrator's second reference to philosophy, in which the philosopher "says that nothing thicker than a 
knife's blade separates happiness from melancholy" (45), the narrator makes an observation about the way the mind functions at this point in history: "For that was the way his mind worked now, in violent see-saws from life to death stopping at nothing in between" (46). In the world of binary oppositions, there is either male or female, life or death, right or wrong, and if humans would understand the world aright, they must adopt a conceptual system that would clearly identify and define what each polar conceptual opposite is in and of itself. But after the demise of philosophy, the mind functions much differently, which leads to a new view of the concept: "everything was partly something else, and each gained an odd moving power from this union of itself and something not itself so that with this mixture of truth and falsehood her [Orlando's] mind became like a forest in which things moved; lights and shadows changed, and one thing became another" (323). By this point in the novel, which is the year 1928, there are no more references to philosophy or the philosophers (the last reference occurs in the late-nineteenth century [259]), which is only appropriate since the whole traditional paradigm of philosophy has crumbled, according to Woolf's narrator, with the discovery that the concept shifts and evolves such that one thing could even become another. This view is clearly anathema to the traditional lovers of Wisdom, because it implicitly rejects the idea of an immutable, mind-independent concept that is what it is whether humans apprehend it or not.

There are certainly many reasons why Woolf's narrator delivers the deathblow to philosophy and the philosophers in Orlando, but to understand those reasons, I want to turn now to To The Lighthouse. To The Lighthouse showcases two separate approaches to knowledge: Mr. Ramsay and Charles Tansley's philosophical approach, which is defined in terms of "[s]ubject and object and the nature of reality" (23), and Mrs. Ramsay and Lily's approach, which is briefly defined in terms of "intimacy itself," an experience that is considered "not knowledge but unity" at one moment, but then considered "knowledge" the next moment (51). In this novel, while Woolf makes it clear that philosophical knowledge is invalid, it is actually the devastating interpersonal and psychological consequences of adopting a philosophical approach to knowledge that interests her most. I take it that Woolf would not object to philosophical knowledge, even though she considers it false and obsolete, if it were not so destructive. But as it turns out, philosophy makes human connection and intimacy, a basic sensitivity to the needs and desires of human beings, impossible, which is why Woolf wishes to banish philosophy and the philosopher.

Woolf spends considerable time underscoring Mr. Ramsay's occupation. A professional philosopher, Mr. Ramsay certainly does not earn enough money to be a wealthy man. As the narrator wryly interjects: "To feed eight children on philosophy!" (22). While Mr. Ramsay may not be affluent, he has earned some respect in his profession, which is apparent from his disciple, Charles Tansley, 
who refers to Ramsay as the "greatest metaphysician of the time" (37). Specifically, Tansley is enticed by a Bertrand Russell approach to philosophy, which is described as "some branch of mathematics or philosophy" (7).

Highlighting Mr. Ramsay's philosophical orientation towards life is important, because it explains his serious epistemological limitations. Mr. Ramsay's flaws in perception are certainly obvious to everyone around him, especially his wife, for as Mrs. Ramsay claims:

His understanding often astonished her. But did he notice the flowers? No. Did he notice the view? No. Did he even notice his own daughter's beauty, or whether there was pudding on his plate or roast beef? He would sit at table with them like a person in a dream. (70)

It is "his narrowness, his blindness" (46) that so irritates Mrs. Ramsay. What explains Mr. Ramsay's inability to see the mundane objects of everyday living is his philosophical focus on metaphysics. Following Plato, Mr. Ramsay treats quotidian objects as pale reflections of an Ideal Form. For instance, while having a discussion with his wife, Mr. Ramsay fails to take note of the physical world: "He did not look at the flowers, which his wife was considering, but at a spot about a foot or so above them" (66). For Woolf's philosopher, the material object is a mere imitation of an immaterial essence, so instead of focusing his attention on the paltry item in front of him, which has no real existence for him because it is composed of secondary qualities, he concentrates on the metaphysical reality that stands a little more than twelve inches above the object, that immutable, mind-independent Concept (an Ideal Form of sorts) which is more real and more true than the ephemeral object.

In addition to distinguishing reality and appearance, Mr. Ramsay subscribes to a teleological worldview. Each generation of philosophers adds to the finite fund of knowledge, and when a truly gifted philosopher comes upon the scene, he could contribute to the linear alphabet of logic and truth (like "the alphabet from A to Z" [35]). In this world, the ultimate epistemic destination is philosophical in nature, the absolute philosophical Truth toward which all knowledge tends.

Indeed, as a philosopher, Mr. Ramsay has adopted a metaphysician's perspective of the world, which is to say that he sees the world through the perceptual lens of "angular essences." So if Mr. Ramsay were to experience "lovely evenings, with all their flamingo clouds and blue and silver," he would reduce it all "to a white deal four-legged table" (23). In short, the philosopher's ability to make razor-sharp distinctions has made him capable of demarcating the exact form of objects in the world (assuming, of course, that such an exact form exists) but incapable of seeing or experiencing the wave-like fluidity of an undemarcatable world. To highlight this epistemological flaw, Mr. Ramsay is pictured in terms of an "arid scimitar," an ancient Asian sword that, like 
metaphysics, belongs in a museum instead of contemporary society. With this epistemological weapon he smites "through the leaves and flowers even of that happy world [the world that James shares with his mother] and making it shrivel and fall"(186). Mr. Ramsay may have a gift for making clear categorical distinctions, but his philosophical gift destroys the world.

There are a few important assumptions at the base of Mr. Ramsay's philosophical orientation toward knowledge: a metaphysical Truth, which is more real and more valid than the physical object, exists; philosophers, more than anyone else, are epistemologically superior and therefore best stationed to apprehend that Truth; true knowledge involves an accumulation of established metaphysical facts that tend toward an ultimate end; and philosophical truth entails razor-sharp categorical distinctions. But if these assumptions turn out to be false, then the philosopher's system of knowledge would be a rhetorical and psychological imposition on rather than a neutral and objective account of the world.

Ironically, Mrs. Ramsay and Lily Briscoe, who implicitly reject Mr. Ramsay and Charles Tansley's philosophical assumptions, have a much more sophisticated understanding of knowledge than the two philosophers. Unlike Mr. Ramsay, who sees knowledge in terms of a teleological progression culminating with a final metaphysical Truth, Lily does not see knowledge as building toward a final philosophical pronouncement. Instead, she thinks of knowledge in non-teleological terms: "little daily miracles, illuminations, matches struck unexpectedly in the dark" (161). Indeed, the narrator shares Lily's view of knowledge, for when Mr. Ramsay resolves himself to the fact that he will never complete the alphabet of Truth, the narrator directly contradicts the aging philosopher with the parenthetical remark: as "if thought ran like an alphabet from A to Z" (120).

Given this rejection of a cumulative system of immutable Truths, Mrs. Ramsay and Lily focus on the contingent knowledge of the human inner life. Specifically, what interests both women is knowledge of the unconscious, the very knowledge that philosophy rejects as non-rational and therefore nonexistent, according to Freud and Rampion. Woolf examines this idea through Mrs. Ramsay's experience with the subconscious colonizing impulse of religious discourse, an idea that she first examined in her 1925 short story "A Simple Melody," which was a trial run for Mrs. Ramsay's experience with the semiotic unconscious of religious discourse. ${ }^{8}$ In this story, Woolf creates George Carslake, a character who mocks believers: "To believe in God indeed! When every rational power protested against the crazy and craven idiocy of such a saying!" (203). Ironically, Carslake discovers that, despite his overt atheism, "he had been trapped into the words. 'To believe in God." As an atheist, Carslake specifically resents how he is trapped into belief through language. Whatever phrase he uses, however mundane, tinkles "in his ear with a sham 
religious flavour," for the religious, according to Carslake, colonize discourse, appropriating and then fashioning it to serve their ends: "Getting home," for example, "the religious had appropriated that. It meant going to Heaven." The word "appropriated" suggests a verbal entrapment, a linguistic imperialism that coerces language users into adopting the theist's discourse whether they are aware of it or not, whether they desire to do so or not.

Like Carslake, Mrs. Ramsay experiences the colonizing impulse of religious discourse. In a weak moment, she says: "We are in the hands of the Lord." But immediately questioning the validity of such a claim, she observes, like Carslake, that she has been "trapped" into belief: "Who had said it? Not she; she had been trapped into saying something she did not mean" (63). On discovering the nature of her situation, Mrs. Ramsay searches "into her mind and her heart, purifying out of existence that lie, any lie" (63). The subtle but coercive discourse of belief entraps Mrs. Ramsay, so to liberate herself, she must probe her inner life and scrutinize the degree to which she has been subjected into being as a religious person. Once she identifies how the theist's "lie" has taken possession of her at the level of the unconscious, she can then begin the process of "purifying" herself. In short, Mrs. Ramsay is not concerned with metaphysical knowledge of the external world, the philosophical dictates of reason; she is interested in something much more basic and fundamental, knowledge of the semiotic unconscious, the very knowledge that predetermines conscious and rational knowledge systems. This is Freud's unconscious "mental processes," which make the rational ego no longer a "master in its own bome" (Standard 285), or Marx's claim that "social being" (389) determines consciousness rather than human consciousness determining a person's being. To my mind, however, Nietzsche is clearest and most insightful in depicting the semiotic unconscious. In the Epilogue to The Case of Wagner, he claims: "But all of us have, unconsciously, involuntarily in our bodies values, words, formulas, moralities of opposite descent - we are, physiologically considered, false" (192). For Nietzsche, the beginning of "knowledge" is to recognize our physiologically false condition. Since we have been claimed at the level of the unconscious by our culture's "values, words, formulas, [and] moralities," we can never be physiologically true. ${ }^{9}$ But we can be less false if we understand that we have been possessed at the level of the unconscious. Only when we acknowledge that our conscious and rational systems of knowledge have been, in large measure, predetermined by the unconscious knowledge that inhabits our bodies can we begin to have a clearer understanding of ourselves. In other words, to have knowledge, one must begin with the tenuous knowledge of the semiotic unconscious. Conversely, to lack such knowledge is to have skewed knowledge, knowledge that is not only distorted but destructive.

Significantly, Woolf clearly indicates that Mr. Ramsay lacks knowledge of the semiotic unconscious. For instance, just after Mrs. Ramsay identifies 
the semiotic unconscious of religious discourse and subsequently exorcises that discourse from her unconscious, Mr. Ramsay enters the scene laughing to himself as he reflects on the older David Hume, who had "grown enormously fat" and was "stuck in a bog" (64). This interjection would seem misplaced were the reader unaware of Mr. Ramsay's thoughts about the eighteenth-century skeptic, but consistent with the theme of being trapped into belief, Woolf's narrator informs the reader nine pages later what specifically causes Mr. Ramsay to laugh: an old woman rescued Hume from the bog "on condition he said the Lord's prayer" (73). Both Mrs. and Mr. Ramsay are confronted with situations in which a person is "trapped" into belief, but while Mrs. Ramsay uses the occasion to interrogate the way such knowledge has taken possession of her from within and then to purge herself of this discourse, Mr. Ramsay dismisses the experience with a laugh. The implication, of course, is that Mr. Ramsay will, at an unconscious level, remain in thrall to the semiotic unconscious of religious discourse, while Mrs. Ramsay has, at an unconscious level, liberated herself. ${ }^{10}$

This distinction between philosophy's metaphysical Truths and Woolf's semiotic unconscious has radical consequences on human knowledge and knowledge of humans. Through reason and logic, philosophy produces metaphysical Knowledge, an immutable system of Truth that has the qualities of being permanent, universal, and/or objective. But if, as Nietzsche and Woolf suggest, the unstable and variable contents of the unconscious significantly influence the way humans frame their experiences, then philosophy's rational and conscious dictates would be profoundly unreliable. But more than that, if the contingent "values, words, formulas, [and] moralities" of the unconscious are the most fundamental part of our uniquely human being, our being as humans, then to know fellow humans we must, first and foremost, understand the mutable and ephemeral contents of the human's semiotic unconscious. Let me briefly indicate how these two approaches to knowledge affect the way people interact with one another.

It is knowledge of the unconscious that makes Mrs. Ramsay and Lily able to understand others and thereby make life more meaningful for those around them. What is most important to Mrs. Ramsay and Lily is the "art" of understanding the inner life ("secret chambers" [51]) of others. As Lily tries to use this "art" to enter the inner life of Mrs. Ramsay, she says that this experience is "not knowledge but unity," but then, in the same sentence, she concludes that it is "intimacy itself, which is knowledge" (51). Knowledge of the unconscious is always tenuous because it relates to "secondary qualities," the contingent "realities" of an individual's psychic life. So when anyone speaks of an intimate knowledge of a person's inner world, there is always the suggestion that this is a provisional form of knowledge. Lily captures the essence of this unstable knowledge when she reflects, much later in the novel, on her intimate experience with Mrs. Ramsay: "Who knows what we are, what we feel? Who knows 
even at the moment of intimacy, This is knowledge?"(171). Intimate knowledge is suggestive, contingent, provisional, so while a knower, like Lily, may have "X-ray" (91) vision of a person's inner life, that knowledge is ephemeral and temporary at best - punctuated with a question mark.

For philosophers, however, who treat "secondary qualities" as non-rational and therefore non-existent, they cannot even see secondary qualities, like the "secret chambers" of a person's inner life. It is such a narrow and narcissistic mindset that compels the Ramsay children to criticize Tansley: "It was him - his point of view" (8) that accounts for his egotistical way of interacting with others, the children claim. For Woolf, there are three separate reasons why philosophers are epistemologically defective and therefore dysfunctional in their relationship with others. The first relates to the philosopher's inability to respect the inner life of another. We see this most readily during the dinner scene, when Tansley criticizes the "silly women" for talking all their "damned rot" (85). Behind Tansley's criticism is the philosopher's primary/secondary distinction. As in Huxley's Point Counter Point, there are realities, like primary qualities, that are more real than mere trifles, like secondary qualities. To highlight this primary/secondary distinction, Woolf has Tansley contrast his philosophical studies and female chit-chat: "He had been reading in his room, and now he came down and it all seemed to him silly, superficial, flimsy" (85). Compared to the deep philosophical realities that he studies, trifling conversation is mere gibberish, so Tansley thinks that it is not worth noting. It is this philosophical mindset that explains Mr. Ramsay's inability to see the people who stand in front of him: "He glared at them [William Bankes and Lily Briscoe] without seeming to see them" (18). Only the deepest realities that philosophy can access have value, so if individuals are not in contact with or do not shed light on those particular realities, they are negligible, virtually non-existent.

This inability to see or appreciate secondary qualities leads to a profound insensitivity, which is the second reason why Woolf faults philosophy. For instance, Mr. Ramsay has the tendency to dismiss the inner life of others as insignificant. Little James Ramsay desires to go sailing to a lighthouse on the morrow, but the philosophical Mr. Ramsay, who attends to factual knowledge instead of individual psychologies, dashes all his son's hope by telling him that the weather will probably not be suitable for such a journey. Mrs. Ramsay, who is more concerned with James's psychological well-being than the weather outlook, cannot understand her husband's blatant disregard for James's feelings. After Mr. Ramsay reiterates his insensitive comments about the imminent bad weather, Mrs. Ramsay observes: "To pursue truth with such astonishing lack of consideration for other people's feelings, to rend the thin veils of civilization so wantonly, so brutally, was to her so horrible an outrage of human decency that, without replying, she bent her head as if to let the pelt of jagged hail, the drench 
of dirty water, bespatter her unrebuked"(32). Does Mr. Ramsay's philosophical pursuit of Truth make him insensitive to his son's personal desires? Or, does his philosophical orientation make him blind to his child's boyhood dream? I suggest that for Woolf philosophical Truth makes individuals epistemologically defective, which leads to an emotional insensitivity. In terms of Mr. Ramsay's philosophical orientation, because the contingent psyche, in relation to the universal and absolute, has no real existence, he cannot see his son's personal needs and desires and the boy's subsequent trauma and crisis.

The final reason, which is logically connected with the first two, why Woolf objects to philosophy relates to the philosopher's tyrannical impulse to coerce and impose on others. Both Tansley and Mr. Ramsay are frequently described in terms of their "exactingness and egotism" (36); "the egotistical man" (38); "he is tyrannical" (46); "He is intolerably egotistical. Worst of all, he is a tyrant" (190). But to say that Tansley and Mr. Ramsay are egotistical and tyrannical is certainly not that shocking, for even the most casual reader of the novel could hardly miss this point. What has yet to be clarified in Woolf studies, however, is precisely how Woolf links philosophy and this coercive, imposing, egotisti$\mathrm{cal}$, and tyrannical mindset. The explanation can be found in the philosopher's claim to metaphysical knowledge - the knowledge that leads to an "ugly imperialism" (536), according to Lawrence. ${ }^{11}$ While the standard person only perceives the secondary qualities of an object or the world, the philosopher sees a stable ontological structure behind the contingent and deceptive world of appearances, and that ontological structure is supposedly more real and more legitimate than the secondary-quality observations of non-philosophers. But if the "values, words, formulas, [and] moralities" of the semiotic unconscious predetermine the philosopher's rational conceptual frame, then secondary qualities would be the only reality and the philosopher's metaphysical Truth would be a fictional creation, something that Huxley's smirking monkey implicitly communicates in the closing lines of the "First Philosopher's Song." In other words, if the non-empirical metaphysical world is nothing more than an imaginary construction, then the philosopher's primary/secondary (reality/appearance) distinction would be null and void. ${ }^{12}$

We see the precise character of the philosopher's mindset through Tansley's and Ramsay's interactions with others, which William Bankes articulates in his observations about Tansley: "for Mr. Tansley seemed to be saying, You have wasted your lives. You are all of you wrong. Poor old fogies, you're hopelessly behind the times" (94). Like Mr. Ramsay, Tansley conceives of knowledge in teleological terms, and since Bankes and company have failed to keep pace with developments in philosophy, their views of the world are insignificant and even wrong - they are still trapped in $\mathrm{O}$ or P. On this view, it is the philosopher's superior epistemology, which leads to superior knowledge, that justifies the philosopher's egregious acts of imposition on others. After all, if the uninformed 
masses lack the philosopher's refined perceptual faculty, their judgments can be neither trusted nor respected. This explains why Mr. Ramsay feels justified in compelling James and Cam to go to the lighthouse late in the novel:

He had made them come. He had forced them to come. In their anger they hoped that the breeze would never rise, that he might be thwarted in every possible way, since he had forced them to come against their wills. (162-63)

Given Mr. Ramsay's superior understanding of humans and the world, it only stands to reason that he would know what is best for James and Cam and would therefore be best stationed to make decisions on their behalf.

But if the philosopher's metaphysical reality turns out to be an epistemic construction of the will rather than an objective discovery of the intellect, then the philosopher would be guilty of asserting and imposing a rhetorical will to power on others instead of providing a neutral and objective system of knowledge. And since the narrator of To The Lighthouse identifies philosophical knowledge as false, we can assume that Tansley and Mr. Ramsay's claims to superior knowledge are really efforts to conceal their self-serving acts of power over others. Mrs. Ramsay specifically notes this ruthless will to power in Tansley. After Bankes praises the Waverly novels, Tansley "denounced" them "when he knew nothing about it, nothing about it whatsoever." What Tansley says discloses nothing about the Waverly novels, but it does reveal much about him, for as Mrs. Ramsay says to herself: "He wanted to assert himself, and so it would always be with him till he got his Professorship or married his wife, and so need not be always saying, 'I-I-I' (106). But getting a Professorship certainly did not eliminate this tendency in Mr. Ramsay, for the elderly philosopher imposes on Lily just as Tansley imposes on Bankes and Mrs. Ramsay: "Let him [Mr. Ramsay] be fifty feet away, let him not even speak to you, let him not even see you, he permeated, he prevailed, he imposed himself" (149). Both Tansley and Mr. Ramsay assume that they perceive a deeper reality than those around them, and as a consequence, they feel justified in imposing their view on others. But since their metaphysical Truth is just a construction of the will, which the text underscores by focusing on the philosopher's tyrannical tendency to impose, rather than a neutral and objective mind-independent reality, their philosophical orientation leads them to commit egregious acts of imposition, which they cannot even recognize, identify, or understand as imposition. In short, Mr. Ramsay and Tansley are victims of philosophy, which leads them to victimize others.

But Mr. Ramsay does have a moment when he finally overcomes philosophy, and significantly, it is at this moment that he experiences an intimacy, which is knowledge, similar to that of Lily and his wife. In the closing moments of the novel, when Mr. Ramsay, James, and Cam finally arrive at the lighthouse, Mr. Ramsay is pictured as if he were taking a leap of atheism: "He rose and 
stood in the bow of the boat, very straight and tall, for all the world, James thought, as if he were saying, "There is no God"' (207). This atheistic reference would be nearly impossible to understand were the reader unaware of the two types of knowledge that Woolf has been strategically outlining throughout the novel. Earlier in the novel, Mrs. Ramsay searches her heart and mind in order to purge herself of a knowledge system (theological in nature) that has taken possession of her from within. Mr. Ramsay, by contrast, focuses on Knowledge of the external world, "subject and object and the nature of reality." Not surprisingly, when Mrs. and Mr. Ramsay are confronted with situations in which a person is trapped, at the level of the semiotic unconscious, into belief, Mr. Ramsay, unlike Mrs. Ramsay, does not reflect on the consequences of such epistemic incarceration. He does not know how to unearth the semiotic unconscious as it functions and exists within his body, nor does he understand the consequences such knowledge would have on his conscious and rational formulations about the world. Such tenuous knowledge, being a mere secondary quality, does not exist in the strict sense of the word for him, so he cannot see it at this point in the novel. As a consequence, he interacts with others as if his primary/secondary (reality/appearance) distinction is a metaphysical fact of being, and given his commitment to reality, he either cannot see or dismisses as irrelevant that which is secondary, like the ephemeral and contingent contents of the semiotic unconscious. As a result, he simply imposes his philosophically grounded system of Knowledge on others without considering that he has been trapped into believing what he philosophically believes. Cam describes her father's philosophical mentality with absolute precision: "But what remained intolerable, she thought, ..., was that crass blindness and tyranny of his which had poisoned her childhood and raised bitter storms, so that even now she woke in the night trembling with rage and remembered some command of his: some insolence: 'Do this,' 'Do that,' his dominance; his 'Submit to me'” (169-70). Notice how Cam faults her father for blindness before mentioning his tyranny. For Woolf, philosophy's major flaw is embodied in the logical connection: blindness to the semiotic unconscious within self and others makes a person feel justified in arrogantly and tyrannically imposing on others.

But by the end of the novel, when he is no longer pondering philosophical issues (significantly, the references to philosophy and the philosopher disappear by the end of the novel, as they do in Orlando), Mr. Ramsay finally takes the same journey as his wife, purging his inner life of the theological lie that holds him captive at the level of the semiotic unconscious. In other words, the atheistic reference suggests that he has, like his wife, finally seen and identified the contents of the semiotic unconscious, which enables him, like his wife, to purge his inner life of the theological lie that once held him and his wife captive. Such an understanding of the semiotic unconscious may undermine his philosophical commitment to the immutable Truths of metaphysics, but 
it does make him able to see and understand the inner lives of other people. For instance, now that he has put philosophical Knowledge behind him and embraced Lily's and his wife's tenuous "knowledge," he, not surprisingly, experiences a moment of intimacy with his children. Normally absorbed in his own world and therefore obtuse to the inner life of others, Mr. Ramsay never gives his son what he secretly needs and desires. What James wants most is his father's approval, something that Mr. Macalister gives James when he says that "'He's doing very well"' (204) in steering the boat to the lighthouse. Macalister's remark leads James to think: "But his father never praised him." And yet, as they near the lighthouse, Mr. Ramsay finally says to his son: "Well done" (206). This simple compliment indicates that Mr. Ramsay has been able, for the first time in the novel, to understand and appreciate James's inner life, which Cam understands quite clearly:

There! Cam thought, addressing herself silently to James. You've got it at last. For she knew that this was what James had been wanting, and she knew that now he had got it he was so pleased that he would not look at her or at his father or at any one. (206)

In word and deed, Mr. Ramsay has finally learned how to see, understand, and appreciate the unconscious desire of his son, that which exists in the "secret chambers" of James's interior life. But such "knowledge" has only become possible now that he has put the metaphysical Knowledge of philosophy behind him. Indeed, To The Lighthouse and Orlando are difficult to understand without taking into account the disappearance of philosophy. But for Woolf, we should welcome the death of philosophy, for with its death, human intimacy and sensitivity become possible.

III.

"I don't want 'a philosophy' in the least."

-(Virginia Woolf, DIARY 4:126)

Given my interpretation, I want to suggest a new approach to Woolf and philosophy. When scholars discuss Woolf's treatment of philosophy, they have tended to frame the debate incorrectly. The interpretive strategy has been to defend Woolf from the charge of not being philosophical, as if being philosophical were a badge of honor legitimizing her intellectual work or as if her intellectual goal were to be philosophical. For example, in The Singing of the Real World, Hussey counters Leonard Woolf's assertion that Virginia "had 'no philosophy of life" by claiming that Virginia "Woolf's art ... is implicitly philosophical" (xi). Similarly, Penelope Ingram challenges Erwin Steinberg's 
"suggestion 'that Woolf expressed not only a lack of interest in any particular philosophy and, indeed, in philosophy as a study in general" by arguing that "in To The Lighthouse Woolf formulates a philosophy" (82). In The Phantom Table, Banfield dismisses the idea "that Woolf's grasp of the whole import of Russell's philosophy was at best vague and at worst wrong" by claiming that Woolf's "work and her aesthetic seize the real possibilities of Russell's thought for art" (xiii), which leads Banfield to refer to Woolf's work as a "philosophically inflected aesthetic" (54). In each one of these cases, the scholars take philosophy as a marker signifying profound intellectual depth, and since they all consider Woolf a serious thinker, they conclude that she must therefore be philosophical. In my analysis, however, I follow Woolf, who says in her diary: "I don't want 'a philosophy' in the least."

My work, which is in the same tradition as Melba Cuddy-Keane's, not only draws a very different conclusion from scholars like Hussey, Ingram, and Banfield about Woolf's treatment of and attitude towards philosophy, but also frames the discussion in an entirely different manner. In her brilliant study, Virginia Woolf, the Intellectual, and the Public Sphere, Cuddy-Keane convincingly argues that Woolf's understanding of the unconscious radically inflected her experience of reading, knowledge, aesthetics, and life. According to Cuddy-Keane, the "dominating political self-consciousness" of Woolf's time "excluded the unconscious - and its fertilizing richness" (103). Instead of clearly demarcating the unconscious and the conscious, rather than subjecting the unconscious to the piercing scrutiny of the conscious intellect, Cuddy-Keane insightfully claims that "unconscious assimilation," for Woolf, "is not prior to conscious apprehension; it is an ever-present, formative participant enabling the apparent seamlessness of conscious thought" (125). Therefore, Cuddy-Keane concludes that the unconscious "is an active and creative participant in thought" (125).

Cuddy-Keane does not specifically examine how Woolf's understanding or experience of the unconscious relates to or undermines philosophy, but she does argue, as I do, that the "radical work of the unconscious supplants normalized rationality" (129). While I am certainly sympathetic to Cuddy-Keane's overall project and convinced by her patient and thorough analyses of Woolf's texts, I do want to use my work on modernist anti-philosophicalism to qualify her view of the Woolfian unconscious. Many modernists, including Woolf, recognized that in the western intellectual tradition, for knowledge to be Knowledge, it must be conscious and rational, and since philosophy has claimed privileged access to that which is conscious and rational, it therefore claims to stand on the highest rung on the intellectual chain of being. But if Cuddy-Keane is right, that "the solidity of the rational logical world of language is disrupted as we descend into the unconscious" (128), then the philosopher's rational and logical claims would be profoundly untrustworthy. And yet, for Woolf, the problem 
is not just the unreliability of philosophy's "truths"; the problem is that the valorization of philosophy's rational and conscious precepts as objective, timeless, and/or universal ultimately renders the semiotic unconscious ephemeral, contingent, and therefore irrelevant. According to Woolf, therefore, those who have internalized the philosopher's orientation toward knowledge will not only dismiss manifestations of the unconscious as insignificant and, in a certain sense, non-existent; they will fail to see such manifestations altogether.

For Woolf, this blindness to the reality of the unconscious can and does have devastating consequences on the capacity of humans to interact with others in a productive, meaningful, and life-invigorating manner. At this point, I want to set my work on the unconscious off from Cuddy-Keane's. For CuddyKeane, the Woolfian unconscious is treated as a positive, near-benevolent force. Described in terms of "its fertilizing richness" (103), it is "the writer's source of inspiration" (131). In other words, the "unconscious ... is envisioned as an active, creative mode" (124). While I do not disagree with this interpretation, I would add that Woolf also treats the unconscious as a potentially tyrannical force, something that could debilitate and destroy relationships. We see this first through the philosophers' failure to acknowledge or understand the semiotic unconscious, which leads them to lack epistemological humility, the self-reflexive ability to question the unconscious frame of reference that predetermines their conscious framing of the world. Failure to see or to take into account the semiotic unconscious can lead people to adopt a mentality that they do not even believe that they believe, as did Mr. and Mrs. Ramsay with regard to theological discourse. Therefore, for those who fail to identify the unconscious discourse that has taken possession of them from within, there is the real danger that they will impose on others a discourse that they do not believe. So the philosophers' blindness to the unconscious debilitates in two ways: it makes them epistemologically arrogant, such that they do not and even cannot question the legitimacy of their rational and logical conceptual frame; and it therefore makes them vulnerable to projecting a discourse on others that they do not even believe that they believe. Only by acknowledging the existence of the semiotic unconscious and by subjecting it to intense scrutiny, purging out of existence any lie that has taken possession of them from within, is it possible to neutralize its potentially tyrannical effect over them.

This critique of the philosophical mindset is crucial in Woolf's project to create the epistemological conditions for experiencing human intimacy. If the semiotic unconscious, as "creative mode" and/or tyrannical power, is the basis and foundation of our uniquely human being, our being as humans, then ignorance of it would make us incapable of knowing and/or connecting with other humans. Therefore, to experience "intimacy itself, which is knowledge," one must acknowledge the existence of the ever-mutable and always-contingent semiotic unconscious. Having done that, one could develop the "art" of pressing 
through into the "secret chambers" of a person's complex interior. Acknowledging the existence and primacy of the semiotic unconscious may be, according to Woolf, devastating for philosophers, since the semiotic unconscious implicitly casts doubt on philosophy's metaphysical mind and absolute Truth, but acknowledging its existence and power also has the virtue of enabling people to understand and appreciate the inner lives of others, something that makes human intimacy possible. For Woolf, we only have much to gain by embracing the semiotic unconscious and abandoning philosophy.

Significantly, this engagement with and revaluation of philosophy was a major concern for much of her career. While it is clear, as Ingram and Tom Regan argue, that the philosopher G.E. Moore heavily influenced Bloomsbury in general, and Woolf in particular, it is also clear that Woolf started to wonder as early as 1920 why someone like Moore exerted so much influence on her intellectual circle: ${ }^{13}$ "I don't see altogether why he [Moore] was the dominator \& dictator of youth" (Diary 2:49). Indeed, Woolf cleverly invokes Plato's image of the cave ("Perhaps Cambridge is too much of a cave") to explain why so many in her circle were intellectually seduced - trapped in Cambridge's Plato-like cave, Bloomsbury writers were too easily enticed by the siren song of Moore's philosophy. My claim is not so much that Ingram and Regan are wrong, as it is that Woolf, while influenced by philosophy early in her career (1904-1919), had a radical change of heart around the year 1920, which led to her direct and focused assault on philosophy in the mid to late 1920s.

What accounted for that change of heart was her attempt to understand her father, who had a philosophical mind but who had virtually no ability, according to Woolf, to understand individual human beings. As Woolf says of her father in her autobiography, he was "conscious of his failure as a philosopher" ("Sketch" 145), a characterization that certainly brings Mr. Ramsay to mind. In fact, Stephen bears a striking resemblance to Mr. Ramsay in "his severe love of truth" (134), his "tyrannical" (106) behavior, and his incessant "egotism" (147). But what is most relevant for the argument of this essay is Stephen's inability to understand human character. As she says of her father:

The reason for that complete unconsciousness of his own behaviour is to be found in the disparity, so obvious in his books, between the critical and the imaginative power. Give him a thought to analyse, the thought say of Mill or Bentham or Hobbes, and he is (so Maynard told me) a model of acuteness, clarity, and impartiality. Give him a character to explain, and he is (to me) so crude, so elementary, so conventional that a child with a box of chalks could make a more subtle portrait. (146)

What accounts for his conventional simplicity, as I have been trying to argue throughout this essay, is his refusal or inability to understand and/or appreciate 
the subtle "reality" and workings of the semiotic unconscious, that tenuous world that philosophers, according to Freud, refuse to acknowledge. Of course, one could argue that it is the failure, and not philosophy ("conscious of his failure as a philosopher"), that makes both Mr. Ramsay and Stephen such unbearable figures, but the combined assault on philosophy found in Orlando and To The Lighthouse coupled with Woolf's rejection of philosophy and its distinctive approach to knowledge suggest that Woolf faulted philosophy. So when Woolf was working most intensely through her relationship with her father, that is, when she was writing To The Lighthouse, ${ }^{14}$ she was looking for some sort of overarching explanation to make sense of characters like Mr. Ramsay and Tansley, and it was in her father's philosophical orientation toward knowledge that she found an answer.

Based on my findings in this essay, therefore, I want to suggest an alternative frame for understanding Woolf's treatment of philosophy and, more generally, modernist anti-philosophicalism. Instead of assuming that philosophy signifies intellectual depth, as Hussey, Ingram, and Banfield do, I would suggest approaching Woolf, as well as many modernists, in terms of their scathing critique of philosophy. Something intrinsic to the philosophical mindset epistemologically disables and debilitates people, such that philosophically-inclined individuals tend to be arrogant and autocratic and consequently cannot enter into healthy or productive relationships with others. What causes philosophy and philosophers to be so narrow, limited, and ultimately destructive? The answer to this question differs considerably from one modernist to the next. What we need are more studies that use a new frame to discuss the literary modernist assault on philosophy. But if my findings in this essay are convincing, what we can say about Woolf and philosophy is this: to have an intimate understanding of Woolf and her work, we must first banish philosophy and the philosopher.

\section{Notes}

1. I would like to thank Pamela Caughie, Mark Hussey, and the JML's editorial reader for helping me better focus the argument of this essay and for their insightful feedback on my work.

2. Aristotle makes this point directly in the Poetics: "poetry is something more philosophic and of graver import than history, since its statements are of the nature rather of universals, whereas those of history are singulars." Poetry is superior to history only insofar as it approximates the highest forms of knowledge, which are "philosophic" (1464) in nature.

3. For excellent discussions of the Cambridge Apostles' extensive influence on Bloomsbury writers, see S.P. Rosenbaum's Victorian Bloomsbury: The Early Literary History of the Bloomsbury Group Volume 1 (161-238) and Ann Banfield's The Phantom Table (1-55).

4. For an excellent discussion of Wittgenstein's post-Tractatus silence, see Ray Monk's Ludwig Wittgenstein: The Duty of Genius (169-253). 
5. For an excellent discussion of the early-twentieth century conflict between psychology and philosophy, specifically the way psychology posed a threat to the basic premises of philosophy, see Martin Jay's essay, "Modernism and the Specter of Psychologism."

6. For an insightful discussion of the way psychology began to emancipate itself from philosophy in the late-nineteenth and early-twentieth centuries, see Judith Ryan's The Vanishing Subject: Early Psychology and Literary Modernism.

7. In a recent discussion about Woolf's rejection of philosophy, Mark Hussey asked me how I can justify my claim when Woolf refers to what she "might call a philosophy" in $A$ Sketch of the Past. My reply was/is this: Woolf was an atheist, but in her Diaries, she frequently uses phrases like "God knows."When I mention Woolf's rejection of philosophy, I mean that she rejected the formal discipline of philosophy in the same way that she formally renounced belief in God. But rejecting God and philosophy does not mean that she can't use the concepts in a looser, more general sense. I want to specifically thank Mark and Pamela Caughie for helping me work though this distinction.

8. For a discussion of this short story and how it is a trial run for the creation of Mr. and Mrs. Ramsay, see my essay, "The Gender of Atheism in Virginia Woolf's 'A Simple Melody."

9. For a more in-depth analysis of this idea of being physiologically false, see my essay, "Killing God, Liberating the 'Subject': Nietzsche and Post-God Freedom." For a discussion of this idea specifically within the context of Woolf's works, see my essay, "Atheism and Sadism: Nietzsche and Woolf on Post-God Discourse."

10. For a more in-depth analysis of Woolf's treatment of the semiotic unconscious of religious discourses, see my essay, "Virginia Woolf and T.S. Eliot: An Atheist's Commentary on the Epistemology of Belief."

11. Levinas refers to the tyrannical impulse of philosophy as a form of "ontological imperialism" (44).

12. Nietzsche traces the breakdown of the distinction between the real and apparent worlds in Twilight of the Idols: "We have abolished the real world: what world is left? the apparent world perhaps? ... But no! with the real world we have also abolished the apparent world?" (51).

13. In Bloomsbury's Prophet, Tom Regan rightly argues that Moore's Principia Ethica was considered a sacred book for Bloomsbury writers. While I agree with Regan's claim, I would only add that Woolf changed her view considerably during the 1920s. My objective in this essay is to explain why.

14. In "A Sketch of the Past,"Woolf clearly indicates that To The Lighthouse was her attempt to come to terms with her rage against her father (108).

\section{Works Cited}

Aristotle. Poetics. Trans. Ingmar Bywater. New York: Random House, 1941.

Banfield, Ann. The Phantom Table: Woolf, Fry, Russell and the Epistemology of Modernism. Cambridge: Cambridge University Press, 2000.

Caughie, Pamela L. Virginia Woolf $\mathcal{E}$ Postmodernism: Literature in Quest $\mathcal{E}$ Question of Itself. Urbana and Chicago: University of Illinois Press, 1991.

Conrad, Joseph. Under Western Eyes. New York: The Modern Library, 2001.

Cuddy-Keane, Melba. Virginia Woolf, the Intellectual, and the Public Sphere. Cambridge: Cambridge University Press, 2003.

Freud, Sigmund. The Ego and the Id. Trans. James Strachey. New York and London: W.W. Norton \& Co., 1989. 
-The Standard Edition of the Complete Psychological Works of Sigmund Freud: Volume 16. Trans. James Strachey. London: Hogarth Press, 1963.

Hulme, T.E. Speculations: Essays on Humanism and the Philosophy of Art. Ed. Herbert Read. London: Routledge \& Kegan, 1965.

Hussey, Mark. The Singing of the Real World: The Philosophy of Virginia Woolf's Fiction. Columbus: Ohio State University Press, 1986.

Huxley, Aldous. Leda. New York: George H. Doran, 1920.

- Point Counter Point. Normal, Illinois: Dalkey Archive Press, 2001.

Ingram, Penelope. "'One Drifts Apart': To The Lighthouse as Art of Response." Philosophy and Literature 23.1(1999): 78-95.

Jay, Martin. "Modernism and the Specter of Psychologism." Modernism/Modernity 3.2 (1996): 93-111.

Lackey, Michael. "Atheism and Sadism: Nietzsche and Woolf on Post-God Discourse." Philosophy and Literature 24.2 (2000): 346-363.

—_. "The Gender of Atheism in Virginia Woolf's 'A Simple Melody." Studies in Short Fiction 35 (1998): 49-63.

__ .Killing God, Liberating the 'Subject': Nietzsche and Post-God Freedom." Journal of the History of Ideas 60.4 (October 1999): 737-754.

_. "Virginia Woolf and T.S. Eliot: An Atheist's Commentary on the Epistemology of Belief." Woolf Studies Annual 8 (2002): 63-90.

Lawrence, D.H. "Why the Novel Matters." Phoenix: The Posthumous Papers of D.H. Lawrence. Ed. Edward D. McDonald. New York: The Viking Press, 1936.

Levinas, Emmanuel. Totality and Infinity. Trans. Alphonso Lingis. Pittsburgh: Duquesne University Press, 1969.

Marx, Karl. "Preface to A Critique of Political Economy." Karl Marx: Selected Writings. Ed. David McLellan. Oxford: Oxford University Press, 1977.

Monk, Ray. Ludwig Wittgenstein: The Duty of Genius. New York: The Free Press, 1990.

Nietzsche, Friedrich. The Case of Wagner. The Birth of Tragedy and The Case of Wagner. Trans. Walter Kaufmann. New York: Vintage Books, 1967.

__. "On Truth and Lies in a Nonmoral Sense." Philosophy and Trutb: Selections from Nietzsche's Notebooks of the Early 1870's. Ed. and trans. Daniel Breazeale. New Jersey: Humanities Press, 1990.

—. Twilight of the Idols. Trans. R. J. Hollingdale. London and New York: Penguin, 1990.

Regan, Tom. Bloomsbury's Prophet: G.E. Moore and the Development of His Moral Philosophy. Philadelphia: Temple University Press, 1986.

Rorty, Richard. Contingency, Irony, and Solidarity. Cambridge: Cambridge University Press, 1989.

_. "Analytic and Conversational Philosophy." A House Divided: Comparing Analytic and Continental Philosophy. Amherst: Humanity Books, 2003.

Rosenbaum, S.P. Victorian Bloomsbury: The Early Literary History of the Bloomsbury Group: Volume 1.2 vols. New York: St. Martin's Press, 1987.

Ruotolo, Lucio. Six Existential Heroes: The Politics of Faith. Cambridge: Harvard University Press, 1973.

Russell, Bertrand. "Seems, Madam? Nay, It Is." in Why I Am Not a Christian. New York and London: W.W. Norton, 2001. 
Ryan, Judith. The Vanishing Subject: Early Psychology and Literary Modernism. Chicago: University of Chicago Press, 1991.

Wittgenstein, Ludwig. Tractatus Logico-Philosophicus. Trans. C.K. Ogden. London and New York: Routledge \& Kegan Paul LTD, 1988.

-Wittgenstein's Lectures: Cambridge 1930-1932. Ed. Desmond Lee. Totowa, New Jersey: Rowman and Littlefield, 1980.

Woolf, Virginia. The Diary of Virginia Woolf: Volume Four, 1931-1935. Ed. Anne Olivier Bell. San Diego: Harcourt Brace \& Company, 1982. 1984.

- Orlando: A Biography. New York: Harcourt, Inc., 1956.

. "A Simple Melody." The Complete Shorter Fiction of Virginia Woolf. Ed. Susan Dick. New York: Harcourt Brace, 1989.

—_. "A Sketch of the Past." Moments of Being. San Diego, New York, and London: Harcourt Inc., 1985.

—. To The Lighthouse. New York: Harcourt Brace, 1981.

Woolf was one of many modernists who led an assault on philosophy. Given her anti-philosophical orientation, those scholars who use philosophy to interpret Woolf, I argue, are implicitly at odds with her aesthetic. Crucial to my argument is Woolf's conception of what I refer to as the semiotic unconscious, which predetermines the conceptual systems we use to systematize our experiences of the world. Based on my findings, I suggest an alternative frame for understanding Woolf's treatment of philosophy and, more generally, modernist anti-philosophicalism. Instead of assuming that philosophy signifies intellectual depth, as many scholars do, I suggest approaching Woolf, as well as many modernists, in terms of their scathing critique of philosophy. What we need are more studies that use a new frame to discuss the literary modernist assault on philosophy. As for Woolf, I conclude: to have an intimate understanding of her work, we must first banish philosophy and the philosopher.

Keywords: Virginia Woolf / philosophy / unconscious / intimacy / knowledge 